\title{
Entrevista com a Professora Doutora Maria de Lurdes Marquês Serrazina - Universidade de Lisboa - Portugal
}

\author{
Adriana Miola' \\ Universidade Federal da Grande Dourados, Faculdade de Ciências Exatas e Tecnologia, \\ Curso de Licenciatura em Matemática e Programa de Pós-Graduação em Ensino de Ciência \\ e Matemática, Professora. \\ https://orcid.org/0000-0002-4757-2554
}

Resumo: A presente entrevista foi parte do plano de trabalho do doutorado sanduíche realizado na Universidade de Lisboa em Portugal ${ }^{2}$ e teve por objetivo compreender as concepções do conceito de desenvolvimento profissional docente. Para isso, realizamos uma entrevista com a Professora Doutora Maria de Lurdes Marquês Serrazina, do Instituto de Educação, em que buscamos por meio de questões conhecer como a pesquisadora têm conceituado o termo desenvolvimento profissional docente (DPD), se é fundamentado em alguma teoria e quais foram as grandes influências para elaboração do conceito de DPD que utiliza em suas pesquisas. A escolha da pesquisadora foi devida ela ser uma das principais referências citadas em muitas pesquisas brasileiras envolvendo o desenvolvimento profissional.

Palavras-chave: Educação Matemática. Formação de Professores. Desenvolvimento Profissional Docente.

Recebido em 19 de janeiro de 2020 Aceito em 22 de fevereiro de 2021

\section{SOBRE A ENTREUISTADA}

A Professora Doutora Maria de Lurdes Marquês Serrazina é doutora em Educação Matemática pela Universidade de Londres - UK (1998), possui mestrado em Educação Matemática pela Universidade de Boston - USA (1984) e licenciatura em Matemática pela Universidade de Lisboa (1972). Atualmente é professora associada convidada no Instituto de Educação da Universidade de Lisboa. Tem como áreas de investigação a Formação de Professores: inicial e contínua. 0 professor como investigador. Prática Reflexiva. Didática da Matemática: matemática

Doutora em Educação Matemática pela Universidade Federal de Mato Grosso do Sul; Mestre em Educação Matemática pela Universidade Federal de Mato Grosso do Sul.

2 Doutoramento intercalar realizado de abril a setembro de 2017 na Universidade de Lisboa/PT pelo Programa de Doutorado Sanduiche no Exterior- PDSE, Edital $n^{\circ} 19 / 2016$. 
do ensino básico, ensino e aprendizagem no ensino básico. Muito conceituada em seu país, em 2007 co-coordenou a equipe que elaborou o novo programa de Matemática do Ensino Básico de Portugal, equivalente à Educação Básica no Brasil, e coordenou a equipe encarregada da elaboração das Metas de Aprendizagem em Matemática para o Ensino Básico em 2009. Entre 2005 a 2011, coordenou o Programa de Formação Contínua em Matemática para Professores do $1^{\circ}$ e $2^{\circ}$ ciclos. Sua produção tem sido divulgada em livros e capítulos de livro.

Pesquisadora: Nas pesquisas que tem desenvolvido, como tem conceituado o termo desenvolvimento profissional docente (DPD)?

Serrazina: Eu penso que desenvolvimento profissional não pode ser desligado do conhecimento profissional, portanto no fundo são conceitos que estão interligados, ou seja, dependem um do outro, o fato de eu desenvolver profissionalmente se eu tiver conhecimento suficiente para isso. Por que? Porque associado ao desenvolvimento profissional estão outros aspectos, como por exemplo, as atitudes. No caso da matemática isso nota-se muito, as atitudes, que se quer do professor de Matemática, isso tudo nos professores das series iniciais, essa questão foca-se muito, quer atitudes para aquilo que os alunos são capazes de aprender em matemática. Há uma crença quase institucionalizada que a Matemática é só para alguns, que nem todos conseguem aprender, isso tudo da sociedade, não só da portuguesa, isso é uma coisa mais geral. E, portanto, esses aspectos todos na minha perspectiva estão interligados quando a gente fala de desenvolvimento profissional. Portanto, desenvolvimento profissional corresponde ao professor desenvolver-se profissionalmente e ao desenvolver-se profissionalmente ele só consegue fazer, se por um lado conseguir perceber qual é o seu papel como professor e como professor que ensina Matemática em termos dos alunos com quem ele trabalha, ou seja, da forma como esses alunos são capazes de aprender Matemática, mas também sobre aquilo que ele é capaz de perceber do que é Matemática. Nos anos iniciais, isso tem muito a ver com questão do conhecimento, do que é conhecimento da Matemática, do que é conhecimento didático, do que é conhecimento curricular. Por exemplo, todo o trabalho que fizemos ligado a formação contínua do professor em um projeto que tivemos, há uma série de anos, foi uma coisa inédita em Portugal, a nossa ideia estava muito nessa perspectiva. Sendo assim, o desenvolvimento profissional tem por um lado a questão do conhecimento, e conhecimento nesses três aspectos: matemático, didático e curricular. Conhecimento matemático, saber a matemática de modo aprofundado, a matemática que ensino. No conhecimento didático, no fundo, é perceber os tipos de tarefas e o modo como devem ser desenvolvidas, como os alunos são capazes de desenvolver ou não, etc, está muito ligada com a questão da sala de aula, como organizar a sala de aula. $E$, depois o conhecimento curricular que tem muito a ver com a questão do currículo, uma vez que tradicionalmente também em Portugal, há alguma ignorância dos currículos, porque os 
currículos são os livros textos, são manuais de instrução. Portanto, a questão do currículo é uma coisa que consideramos importantes. Mas, isso não pode desligar das expectativas sobre o que é que os seus alunos são capazes de fazer e das suas atitudes práticas da Matemática. Desse modo, digamos que tudo isso contribui para o desenvolvimento profissional.

Pesquisadora: 0 conceito de DPD que tem utilizado é fundamentado em alguma teoria?

Serrazina: Sim, tem alguns. No fundo, não se está propriamente fundamentado. A questão é, a ideia do Shulman que definiu a questão do conhecimento do conteúdo, etc. Há alguns contributos da Debora Ball, embora outros não estamos tão de acordo. Ball no fundo especificou o que o Shulman queria dizer e aplicou a Matemática. Mas, quando ela faz aquela "oval", com aquelas divisões todas, considera-se que o conhecimento não se pode partilhar daquela maneira, porque essas coisas são todas interligadas e, portanto, ... Mas, pronto, teve essa contribuição, principalmente para os anos iniciais, porque ela trabalhou, e onde trabalha, isso ajudou-nos um bocado a perceber as questões que se põe nos anos iniciais e como é importante saber a Matemática que ensinam, que não é só saber muita matemática, mas saber de modo aprofundado o que estão a ensinar ou que tem que ensinar e, isso digamos que é um contributo da Debora Ball.

Pesquisadora: Quais foram as grandes influências para elaboração do conceito de DPD que utiliza? A professora falou do Shulman e da Ball. Teriam outros?

Serrazina: Sim, claro. Depois já numa perspectiva que foi trabalhado pelo professor João Pedro da Ponte e alguns doutorandos dele, tem a ver com o conhecimento didático, que não é bem aquilo que chamamos de conhecimento didático no programa de formação. Porque no programa de formação era mesmo a didática, saber a didática e, portanto, tem grande influência nessas definições e na forma de trabalhar a questão do desenvolvimento profissional. Claro que, depois nós temos influências do Christopher Day, que não é da Matemática, mas que de alguma maneira trabalhou as questões do desenvolvimento profissional. 0 próprio Nóvoa que nos seus escritos iniciais, falava muito dos professores e do desenvolvimento profissional e isso tudo há um aspecto que agora nós consideramos muito em nosso trabalho, que é questão da reflexão sobre a pratica, como uma forma de desenvolvimento profissional, na medida em que refletir sobre a pratica. Eu estou a pensar sobre aquilo que ensino, como ensino e o que aconteceu ao que eu ensinei e, portanto, no fundo estão a desenvolver profissionalmente também. Portanto, a questão da reflexão sobre a pratica é uma questão que eu acredito ser fundamental ao nosso processo. 


\section{REFERÊNCIAS}

BALL, D. L.; BASS, H. Toward practice-based theory of mathematical knowledge for teaching. In: DAVIS, B.; SMITH, E. (ed.). 2002 ANNUAL MEETING OF THE CANADIAN MATHEMATICS EDUCATION STUDY GROUP, 2003, Edmonton. Proceedings [...] Edmonton: CMESG/GCEDM, 2003. p. 3-14.

BALL, D. L.; THAMES, M. H.; PHELPS, G. Content knowledge for teaching: what make it special? Journal of Teacher Education, v. 59, n. 5, p. 389-407, 2008.

DAY, C. Desenvolvimento profissional de professores: os desafios da aprendizagem permanente. Porto, Portugal: Porto Editora, 2001.

SHULMAN, L. S. Knowledge and teaching: foundations of the new reform. Harvard Educational Review, v. 57 , n. 1, p. 1-22, 1987.

SHULMAN, L. S. Those who understand: knowledge growth. Teaching Educational Research, v. 15, n. 2 , p. 4-14, 1986.

Endereço para correspondência: Rua Oliveira Marques, 3730, Jardim Paulista, 79830-040, Dourados, Mato Grosso do Sul, Brasil; adrianamiola@ufgd.edu.br 